\title{
Sort etik med transkontekstuel inspiration
}

\author{
Allan Boesaks kontekstuelle etik for de sortes befrielse \\ Lektor Ph.D. \\ Carsten Elmelund Petersen
}

\begin{abstract}
Allan Boesak developed a black liberation theology in South Africa in the time of apartheid. He was studying the thinking of four afro-americans in USA, Martin Luther King, Malcolm X, Albert Cleage, and James Cone. Boesak does not argue that his ethics is universal, because the validity of his black ethics is only in the contexts where there is oppression. Black ethics is contextual, Boesak says. But this article argues that according to Boesak, ethics has validity in all the contexts where there is oppression. The liberation ethic is, therefore, transcontextual. Another foundational element in Boesaks ethics is "the Black": It is the black consciousness that gives black people a sense of belonging when they are oppressed. The Black consciousness is transcontextual. He uses the inspiration from USA, which is his original context, into the South Africa apartheid situation, the application context.
\end{abstract}

Key words: Allan Boesak - contextual ethics - transcontextual foundation - liberation theology - Black Power - Afroamerican inspiration

Langt de fleste, der opstiller en selvstændig etik forudsætter, at den har en universel gyldighedsprætention. Men der er udgaver af etik, hvor det ikke er tilfældet, og hvor gyldighedsområdet er begrænset. Det er tilfældet med nogle udgaver af befrielsesteologisk etik. De har en kontekstuel gyldighedsprætention. De er vokset ud af en smerte, der er opstået lokalt. I 1970'erne og 1980'erne kom denne diskussion mellem det universelle og det kontekstuelle i etikken. Befrielsesteologien drøftes ikke længere, men det er tid til at analysere og se, hvad etikken som fagdisciplin kan lære af denne diskussion.

Et af de forhold, der kan drøftes, er, at befrielsesteologien forudsatte transkontekstuelle størrelser altså forudsætninger, der har gyldighed i mere end en konktekst. Anthony Thiselton bemærkede tidligt i 1990'erne, at befrielsesteologer forudsatte transkonteksuelle 
størrelser. ${ }^{1}$ Notger Slenczka brugte også begrebet. ${ }^{2}$ Men ingen af disse tematiserede transkontekstualiteten. Den følgende drøftelse af Allan Boesaks sorte etik er et bidrag til den tematisering.

Boesaks etik er blevet til i en sydafrikansk kontekst i 1970'erne. Den udspringer af de sortes kamp for lige rettigheder med hvide. Derfor kaldes den sort etik. Den er tillige blevet til i en kristen kontekst, hvorfor Boesak søger at legitimere befrielseskampen ud fra kristen teologi. Boesaks befrielsesteologi er gennemtrængt af ét etisk aspekt: Kampen for humaniteten.

Når det gælder artiklens hovedemne, er Boesaks sorte etik bundet op på to transkontekstuelle størrelser. Den ene størrelse er befrielsesevangeliet, at Gud gennem Israel og Jesus har vist, at han vil befri de undertrykte. Denne transkontekstuelle størrelse har mange anvendelseskontekster bl.a. i apartheidtidens Sydafrika, når Boesak fremstiller en kontekstuel, sydafrikansk, kristen befrielsesteologi.

Den anden afgørende størrelse bag Boesaks etik, er den afrikanske religiøsitet, som ofte kaldes "det sorte". Det er de sortes bevidsthed om samhørighed, når de er undertrykt. Denne størrelse har en oprindelseskontekst i Afrika. Men den har flere anvendelseskontekster, hvor "de sorte" har været under pres. Boesaks sorte befrielsesteologi er udviklet under inspiration fra andre sorte teologer. I det følgende vil den transkontekstuelle størrelse blive påvist ved at se på den inspiration, som Boesaks sorte etik fik gennem Martin Luther King og Malcolm X, der levede i USA.

Boesak bruger ikke selv begrebet transkontekstualitet. Men han forholder sig kritisk til både Albert Cleage og James Cone, som begge er sorte befrielsesteologer fra USA. Cone er den, der fagligt udvikler den sorte befrielsesteologi, som Boesak er meget afhængig af. Men Boesak kritiserer Cones befrielsesteologi og kalder den en regionalteologi som kun er for sorte. Den har et snævert perspektiv, der alene går på de sorte i USA. Cones etik kan betegnes som en kontekstuel etik uden transkontekstuelt udblik. Cleages teologi er endnu mere lukket. Cleage var sort præst og borgerrettighedsforkæmper, som i 1960 udviklede en eksklusiv sort nationalisme i USA.

1. Anthony C. Thiselton, New Horizons in Hermeneutics (Grand Rapids: Zondervan 1992), 410 .

2. Notger Slenczka, "Kontext und Theologie - Ein kritischer versuch zum Programm einer "kontextuellen Theologie"”, Neue Zeitschrift für Systematiske Theologie und Religionsphilosophie 53/3 (1993), 303-331. 


\section{Boesaks befrielsesteologiske studier}

Før 1970 var der næsten ikke udkommet teologisk litteratur i Sydafrika forfattet af andre end hvide. Derfor fik Boesaks forfatterskab stor betydning. Han var en af de første ikke-hvide sydafrikanere, der studerede i Holland. ${ }^{3}$ Der foreligger et mindre studium fra Boesaks tid som doktorandstuderende i Holland. Som en del af studiet var Boesak i USA, hvor han undersøgte nogle af de sorte lederes tænkning. Dette ophold udmøntede sig i en lille afhandling om etikken hos Martin Luther King, Jr. og Malcolm X. ${ }^{4}$ Boesaks doktorafhandling Farewell to Innocence - A Socio-Ethical Study on Black Theology and Power lagde grunden for hans befrielsesteologi. ${ }^{5}$ Den var et gennembrud for befrielsesteologisk litteratur skrevet af ikke-hvide sydafrikanere. Boesak fulgte dette op med andre bøger, som anvendte det etablerede grundlag.

Derudover har Boesak skrevet en lang række taler, breve og artikler, der er trykt på flere sprog. Det betydeligste af de sekundære skrifter er artikelsamlingen Black and Reformed, ${ }^{6}$ som rummer en række taler og artikler fra Boesaks karriere som præst, som moderator for den farvede afdeling af Den hollandsk-reformerte Kirke i Sydafrika og som præsident for De reformerte Kirkers Verdensalliance (WARC). En detaljeret oversigt over Boesaks forfatterskab findes hos Adelbert

3. Allan Aubrey Boesak blev født i 1946 i den lille by Kakamas i Cape-provinsen i Sydafrika. Da han var seks år, døde hans far, og hans mor var alene om at opdrage Allan og hans 7 søskende. Moderen var meget fattig, men også meget stærk i sin kristne tro. I 1963 påbegyndte han det teologiske studium på Den hollandsk-reformerte Missionskirkes præsteseminarium i Sydafrika. 4 år senere afsluttedes uddannelsen. Efter $2 \frac{1}{2}$ års præstetjeneste ønskede Boesak at studere videre i Holland. Han kom i 1970 til Holland. De næste 6 år studerede han ved Det teologiske Akademi i Kampen i Holland og ved to præsteseminarier i New York i USA, inden han i 1976 fik den teologiske doktorgrad ved Det teologiske Akademi i Kampen.

4. Allan Boesak, Coming in out of the wilderness - A comparative interpretation of the ethics of Martin Luther King, Jr. and Malcolm X (Kampen: Kamper Cahiers 1976).

5. Boesaks doktorafhandling blev først udgivet på hollandsk, men udkom på engelsk i 1977 i USA og England: Allan Aubrey Boesak, Farewell to Innocence - A Socio-Ethical Study on Black Theology and Black Power (Maryknoll: Orbis Books 1977).

6. Allan Boesak, Black and Reformed-Apartheid, Liberation and the Calvinist Tradition (Maryknoll: Orbis Books 1984).

7. Ved WARCs generalforsamling i $1982 \mathrm{i}$ Ottawa blev Boesak valgt som præsident for de 70 mill. reformerte kristne i verden. Det var en vidtrækkende beslutning, fordi den hvide hollandsk-reformerte moderkirke i Sydafrika samtidig blev suspenderet fra egentligt medlemsskab i Verdensalliancen. Apartheid havde fäet karakter af status confessionis. Den hvide kirke havde op gennem historien været initiativtager, men var nu isoleret. Boesak var nu tillige blevet et internationalt kendt navn. 
Scholtz. ${ }^{8}$ Boesaks faglige karriere var færdig, allerede inden apartheid var afviklet. I sommeren 1990 fratrådte han sine hverv som præst og præsident for WARC pga. problematiske forhold i hans civilstatus. I 1999 blev Boesak dømt for tyveri af knap tre millioner bistandskroner.' I det følgende vil der blive fokuseret på Boesaks vision fra 1970: Befrielse for de undertrykte sorte.

Det er de to førstnævnte teologiske studier, der er den egentlige basis for resten af forfatterskabet. Boesaks forfatterskab er ikke omfattende. Coming in out of the wilderness er et lille studie på 48 sider, og doktorafhandlingen Farewell to Innocence er på 184 sider. De har dog haft afgørende betydning, hvorfor de er relevante at fremdrage som eksempel på en kontekstuel befrielsesteologisk etik.

I den sydafrikanske befrielsesteologis historie skelnes der mellem første fase og anden fase. Første fase var inspireret af et seminar, som studenterorganisationen SASO arrangerede i 1970, hvor der specielt blev satset på at etablere en sort bevidsthed inspireret af afro-amerikanerne Cone og Cleage. Imidlertid blev bøgerne fra SASO-seminaret og bøgerne af Cone og Cleage bandlyst i Sydafrika. Da Boesaks Farewell to Innocence kom i 1977, blev denne bog den sorte teologis hovedtekst, hvormed anden fase indledtes. ${ }^{10}$ Fra $1977 \mathrm{og}$ frem til 1990 var Boesaks indflydelse på den teologiske, kirkelige og politiske udvikling i Sydafrika betydelig.

\section{Boesaks program}

I forordet til Farewell to Innocence skriver Boesak, at det er et ekstraordinært risikabelt forehavende at involvere sig i befrielsesteologien i den sydafrikanske situation. Men den sorte teologis udfordring og budskab er så vigtigt, at der ingen vej er tilbage. Boesaks afhandling skal være et bidrag til dialogen mellem de kristne i den tredje verden og de kristne i den vestlige verden (Boesak 1977,xi).

I det følgende vil der ikke blive fokuseret på den ene transkontekstuelle størrelse befrielsesevangeliet. Derimod vil betydningen af den anden blive undersøgt i Boesaks udvikling af befrielsesteologi.

8. Adelbert Scholtz, The Story of Allan Boesak (Herford: Busse Seewald 1989), 1421.

9. Jesper Strudsholm, "Boesak-dom en sejr for retsvæsenet", Politiken torsdag 18. marts (1999), 4.

10. Mokgethi Motlhabi, "Introduction", The Unquestionable Right to Be FreeBlack Theology from South Africa, ed. Itumeleng J Mosala and Buti Tlhagale (Maryknoll: Orbis Books 1986), x. 
Sort bevidsthed, sort magt og sort teologi er afgørende begreber for Boesaks fremstilling. Sort bevidsthed defineres som at være klar over, at sorte menneskers humanitet er konstitueret af deres sorthed. De skammer sig ikke længere over at være sorte, at have en sort historie og kultur, der er anderledes end de hvides (Boesak 1977,1). Sort bevidsthed er indgangsporten til sort magt. Sort magt defineres af Boesak som en kritik af og en kraft til ændring af systemer og mønstre i det samfund, som undertrykker de sorte. Det er ikke hudfarven, der er afgørende, men sorthed er snarere bevidstheden om oprindelsen sammen med andre sorte.

Boesak definerer sort teologi; som den teologiske refleksion sorte kristne foretager i den situation, hvor de lever og kæmper for befrielse. Sorte mennesker spørger nemlig: Hvad betyder det at tro på Jesus Kristus, når man er sort og bliver undertrykt af hvide, som kalder sig kristne. Boesak vil sige, at teologerne skal tage de psykologiske, sociale og politiske realiteter i raceforholdene op. Sort teologi udarbejdes i befrielsesteologernes kontekst. Boesak mener også, at sort teologi skal ind på den økumeniske dagsorden for ad den vej at frembringe en irreversibel forandring. Boesak har derfor en erklæret målsætning, at få hjælp udefra. Den sydafrikanske kontekst skal ikke være isoleret fra omverdenen. Boesaks kontekstuelle opfattelse har sans for de tilgrænsende kontekster.

For den kristne socialetik er konsekvenserne af forholdet mellem sort teologi og sort magt afgørende, skriver Boesak (Boesak 1977,2). Boesak forudsætter, at der gives en kristen socialetik. Boesaks anliggende er at udfolde en konkret variant af denne.

Boesak refererer til den nordamerikanske sorte befrielsesteologi. Den sorte teolog Cone skrev i 1969: "It is my thesis, however, that Black Power, is not the antithesis of Christianity, ..... It is, rather, Christ's central message to twentieth century America" (Boesak 1977,2). ${ }^{11}$ Cones påstand blev efterfølgende diskuteret og kritiseret. Det blev drøftet, i hvilken grad kirken skulle involveres i politik (Boesak 1977,2). For Boesak er dette inspirerende og kan oversættes til sydafrikansk sammenhæng. Den sorte befrielsesteologi har en oprindelseskontekst i USA, men Boesak finder, at Sydafrika er en oplagt anvendelseskontekst. Men den kan ikke oversættes ureflekteret.

Boesak nævner med tilslutning, at en gruppe sorte teologer og kirkeledere i USA i 1976 udtalte, at sort teologisk refleksion finder sted i de kontekster, hvor de autentiske erfaringer af Gud gøres i de sortes tilbedende fællesskab. Dette fællesskab har altid været anset for at være et udtryk for frihed under Guds herredømme. Det kan ikke

11. James H. Cone, Black Theology and Black Power (New York: The Seabury Press 1969), 1. 
teoretiseres ved at løsrives fra det konkrete liv. Dette frihedsfællesskab findes i den etiske praksis til trods for racismen og undertrykkelsen. Den sorte kirke må derfor skabe forståelse af troens frihed i den trængte situation (Boesak 1977,2-3).

Den sorte befrielsesteologi vokser såvel i USA som i Sydafrika ud af erfaring og praksis. Det er fokuseringen på erfaring og praksis, der indebærer, at betoningen ligger på det kontekstuelle. Det er meningsløst at tale om en universel etik, når der er så skarpe skel mellem mennesker. Den befrielsesteologiske etik tager det skel alvorligt, der findes mellem fattige og rige, mellem sorte og hvide, mellem undertrykte og undertrykkere. Befrielsesteologien fremmer derved bevidstgørelsen om, hvad der har gjort forskel.

Boesak begrunder ud fra skabelsesberetningen, at Gud har skabt alle mennesker i sit billede. Men han bruger ikke begrebet universalitet i den forbindelse. Det er splittelsen, han fokuserer på. At mennesket er skabt i Guds billede, beskriver menneskets unikke relation til Gud. Det illustrerer også, at alle mennesker er skabt til at have et delt ansvar for skabningen. Men dette delte ansvar er tilsidesat af racismen. Racismen underminerer de sortes selvopfattelse som mennesker skabt i Guds billede. Derfor er racisme ikke kun et problem, der kan forstås $\mathrm{i}$ individuelle begreber. Racismen er ikke oprindelig afrikansk. Den er kommet med koloniseringen. Efter Boesaks opfattelse er racismen en strukturel synd og afgudsdyrkelse, fordi den i praksis fornægter de sortes gudbilledlighed, og derigennem fornægter, at Gud har skabt alle mennesker frie og lige. Når Boesak kalder det afgudsdyrkelse, skyldes det en forvrængning af menneskets gudbilledlighed og derigennem af billedet af Gud selv. De sorte må søge tilbage til den autentiske humanitet, der findes i Jesus Kristus. Boesak er bevidst om, at der er et epistemologisk problem, som tilslører den sande autentiske humanitet. Det er imidlertid ikke kun skabtheden, men også næsten 20 artikler i FNs universelle menneskerettighedserklæring, som tilsidesættes. Boesak omtaler denne erklæring som universel, men han reflekterer ikke over begrebet universalitet $\mathrm{i}$ den forbindelse (Boesak 1984,3,102-104).

Universaliteten nævnes kun i forbifarten, når Boesak skal definere, hvad sort teologi er. Sort teologi er ikke en universel åbenbaring for de sorte, men derimod en sort opfattelse af evangeliet (Boesak 1984,21). Befrielsesevangeliet har således en anvendelseskontekst, hvor de sorte er undertrykt. Det betyder, at evangeliet er en transkontekstuel størrelse, mens den sorte teologi er en kontekstuel størrelse, som er præget af de sortes opfattelse af evangeliet. Boesak siger aldrig, at befrielsesevangeliet er universelt, og det skal forstås på den baggrund, at det har gyldighed, hvor der findes undertrykkelse. Det, som kan identificeres som en universel størrelse, selv om Boesak ikke selv siger det 
eksplicit, er Jesu sande autentiske humanitet. Det er humaniteten, som er målestok for Boesak.

De undertrykte tror på Gud, Jesu Kristi Fader, men ønsker ikke længere at tro på de myter, der underbygger undertrykkelsen. De ønsker ikke at være tilfreds med tingenes tilstand $\mathrm{i}$ et stille håb om, at Gud tager ansvaret for de menneskelige fejl. Boesak siger, at den kristne kirke må sige "a farewell to innocence", simpelthen fordi det er en "pseudoinnocence" (Boesak 1977,3). Der er tale om ironi, når Boesak taler om uskyldigheden. Der er tale om et opgør med den tænkning, der henlægger skyld og ansvar for tingenes tilstand til en anden sfære ved at sige, at det er de andres skyld. De kristne må selv vedkende sig skyld og selv tage ansvaret for at ændre det uretfærdige til det retfærdige. Boesak henter det ironiske skyldbegreb hos en psykolog og præciserer, at der er tale om pseudoskyldighed. Den falske skyldighed er både selvdestruktiv og dæmonisk, fordi den skaber en blindhed, der paralyserer. Den fratager mennesket ansvaret for dets egen situation.

Der må et opgør til, og det må føre til et farvel til uskyldigheden hos de hvide. Deraf kommer titlen på afhandlingen. Det hvide kristne mindretal troede, at de havde et guddommeligt kald til at opretholde vestlig kristen civilisation i Sydafrika (Boesak 1977,4). Fortalerne for dette apartheidsystem troede, at det var et udtryk for kærlighed, når de adskilte sorte og hvide.

Apartheidideologien adskiller sorte og hvide. Der følger en fremmedgørelse mellem sorte og hvide, og det manifesterer separationen af de to hudfarver. Apartheid frakender de sorte den menneskelige kvalitet, som de hvide har. Apartheid bliver på det grundlag kærlighedsløshedens højdepunkt. De hvide magthavere har taget patent på bibelordet "Det er saligere at give end at få" (ApG 20,35), derfor lever de sorte på de hvides nåde og barmhjertighed (Boesak 1977,5). De vestlige kolonimagter har givet kolonierne i den tredje verden selvstændighed. Men de rige lande har stadig magten over de fattige gennem økonomisk afhængighed. Også på dette område må der gøres op med den falske uskyldighed. Den retorik, der tilhører apartheidideologien, giver folk det indtryk, at de hvide er uskyldige. Derfor må de sorte gøre op med deres egen slavementalitet. Den nye sorte bevidsthed må give styrke. Apartheid er nemlig ikke skabt af en uundgåelig kosmisk nødvendighed, men af historiske systemer og strukturer, der er skabt og vedligeholdt af mennesker (Boesak 1977,6).

Den kontekstuelle befrielsesteologi skal tage udgangspunkt i den konkrete erfaring og praksis. Den skal være åben for, at de undertrykte deler deres tro på én Herre, én dåb og én Gud, som er alles fader, og som er over alle, gennem alle og i alle, jf. Ef 4,5-6 (Boesak 1977,6). Det er de undertrykte, der deler denne tro, skriver Boesak. 
Målet er ikke en universel menneskelighed, målet er at afvikle undertrykkelsen. Om, det er det samme, er ikke afgjort, for undertrykkelsen skal afvikles i den konkrete kontekst. Befrielsesetikken har gyldighed i den konkrete kontekst og i lignende kontekster, hvor der er undertrykkelse.

Udgangspunktet er den sydafrikanske kontekst, hvor adskillelsen er reel. Målet er at overvinde adskillelsen. Derfor ligger det i den sorte befrielsesteologis væsen, at den blot er et middel for at nå et mål. Når målet er nået, er midlet overflødigt. Midlet er en situationsbestemt teologi, der både har geografisk og historisk begrænsning. Den er overflødig, hvis apartheid elimineres i Sydafrika, men den vil være relevant $i$ andre lignende kontekster, hvor der er en lignende undertrykkelse.

Boesak har derfor ledt efter inspirationskilder andre steder, hvor sorte har været undertrykt.

\section{To sorte inspirationskilder}

Som analyseobjekt for et delstudie under doktorgradsprogrammet ved Theologische Hogeschool der gereformeerde Kerken i Kampen i Holland valgte Boesak etikken hos to betydelige sorte personer i USA. Martin Luther King, Jr. og Malcolm X var revolutionære personligheder i nyere tid. Begge blev myrdet for deres overbevisning og engagement. ${ }^{12}$ Gennem deres død fik de en martyrlignende status. King gav den sorte kirke nyt håb. Derfor bliver King et af de betydeligste forbilleder for Boesak.

Boesaks tese er, at King skabte den situation, hvor det gik op for de sorte, at de kunne kæmpe og vinde, og det var denne situation, som Malcolm X talte ind i. Derfor fik han betydning. Begge repræsenterer de sortes kamp for befrielse fra undertrykkelse og uretfærdighed. Den størrelse, som i nærværende sammenhæng viser sig at være transkontekstuel, nemlig "det sorte" overskrider de religiøse gruppers grænser. Men det sorte er ikke universelt. Det anerkendes som gyldigt i de kontekster, hvor de sorte lever. Boesak finder dette både hos den kristne Martin Luther King og hos den muslimske Malcolm X. Når Boesak bygger sin egen sorte etik op, er det King, der er afgørende, for hos King er både det sorte og den kristne befrielse til stede. Boesak tager begge dele med, når han i sin egen kontekst opbygger den sorte etik.

12. Martin Luther King, Jr. (1929-1968) var baptistpræst. Malcolm X er et pseudonym for Malcolm Little (1925-1965). Han var i en årrække leder af Black Muslims. 
Boesak foretager en sammenlignende teologisk fortolkning af deres etik. King var baptistpræst og efterlod sig et betydningsfuldt forfatterskab. Malcolm X var ikke teolog eller kristen. Han efterlod sig en selvbiografi og en række taler. Det er kilderne for Boesaks undersøgelse. De to åbnede muligheder for sort revolution, selv om de repræsenterede to forskellige linjer i de sortes historie. De blev myrdet $i$ en fase, hvor de var i færd med at revurdere deres synspunkter. De havde det samme mål: De ønskede radikale ændringer i de amerikanske samfundsstrukturer til fordel for de sorte. De udledte deres synspunkter fra forskellige kilder. King var inspireret af kristendommen og specielt af Bjergprædikenen, mens Malcolm X var radikal muslim. Boesaks intention er ikke at lægge distance til Malcolm X, fordi han ikke var kristen og derfor ikke havde en kristen etik. Det er heller ikke Boesaks anliggende at vurdere, om King har tolket Bjergprædikenen rigtigt med sin ikke-voldsstrategi. Spørgsmålet er snarere, om deres etik er brugbar (Boesak 1976,4,45-48). Studiet har et pragmatisk sigte.

Martin Luther King, Jr. var politisk befrielseskæmper. Men for King har det oprindeligt afrikanske ikke samme betydning, som det har for Boesak. King stillede sig kritisk til f.eks. Marcus Garveys panafrikanske ide, fordi han anså den for at være et udtryk for en raceadskillelsesideologi. ${ }^{13}$ Boesak går heller ikke ind for denne idé, men han er generelt kritisk over for vestlig tænkning. King var præget af vestlig tænkning og ønskede ikke at føre de sorte i USA tilbage til det oprindeligt afrikanske hverken fysisk eller mentalt. King sagde, at den amerikanske neger ikke er hverken totalt afrikaner eller totalt vestlig. Han er en "Afro-American", en ægte hybrid, en kombination af to kulturer. ${ }^{14}$ Men det afrikanske element, det sorte, hørte med, når afroamerikaneren befandt sig i den nordamerikanske kontekst. Boesak tolker King på baggrund af det sorte. Kings etik ønsker, at sorte og hvide kan leve side om side i retfærdighed. Boesak er kritisk over for raceadskillelsestænkning, uanset om den er hvid eller sort. James Cone har tolket King og Malcolm X som komplementære størrelser inden for det afroamerikanske fællesskab. De havde samme mål, nemlig friheden. Men de talte til forskellige grupper af afroamerikanere, og de havde hver deres metode til at nå målet. ${ }^{15}$

13. John J. Ansbro, Martin Luther King, Jr.: The Making of a Mind (Maryknoll: Orbis Books 1984), 198 og 207.

14. Martin Luther King Jr., Where Do We Go From Here: Chaos or Community (New York - Evanston - London: Harper \& Row 1967), 53.

15. James H. Cone, Martin \& Malcolm \& America - A Dream or a Nightmare (Maryknoll: Orbis Books 1991), ix-xi, 1-17, 244-271 og 315-318. 


\section{Kings ontologisk-teologiske udgangspunkt}

King ønskede at gøre Guds vilje. Han var født i en sort, teologisk konservativ baptistisk sammenhæng. Han fik en teologisk uddannelse og var overbevist om, at Bibelen kunne bruges som kilde for den kristne etik. Han voksede op med racemæssig og økonomisk uretfærdighed, og han var ofte vidne til politivold. Det gav ham en bestemt forudforståelse, da han som voksen hentede inspiration gennem læsning af Walter Rauschenbusch' bog Christianity and the Social Crisis, Visser 't Hoofts The Background of the Social Gospel in America og Reinhold Niebuhrs Moral Man and Immoral Society. Gennem Rauschenbusch' opfattelse af det sociale evangelium blev King overbevist om, at mennesket har en naturlig godhed og er i besiddelse af en naturlig tankekraft. Rauschenbusch gjorde gældende, at mennesker elsker og tjener Gud, idet de elsker og tjener deres næste. Dette anvendte Hooft, idet han gav en teologisk-ontologisk begrundelse for etikken. Han understregede, at der er en enhed mellem Gud og universet. Universets normer er således defineret af Gud, der er den iboende lov i alting. Han er i naturen som den naturlige lov, og han er i menneskelivet i form af rationalitet og etisk lov. Det indebærer en gensidig afhængighed. Alle mennesker er børn af samme fader. Hooft mener, at det guddommelige faderskab og det menneskelige broderskab er den eneste naturlige lov. For King lå denne anskuelse som teologisk-ontologisk baggrund for, at han understregede, at mennesket er Guds medarbejder (Boesak 1976,6). Boesak har ikke haft svært ved at identificere sig med King som sort borgerrettighedsforkæmper, men har ikke i samme grad del i de ontologiske overvejelser.

King modtog inspiration til en ikke-voldsholdning fra Mahatma Gandhi. King så i Gandhis måde at reagere på en virkeliggørelse af Kristi ikke-voldelige kærlighedsetik, som særligt kommer frem i Bjergprædikenen. Tolkningen og anvendelsen af Bjergprædikenen har udgjort et problem for kristne med henblik på samfundsetikken. Men King kunne videreudvikle denne ikke-voldstænkning, fordi han gennem Gandhi så, at det er praktisk muligt at elske fjenden og vende den anden kind til (jf. Matt 5,39 og 5,44). King havde tidligere kun kunnet forbinde Bjergprædikenen med individualetikken, men efter læsning af Gandhi kunne det forbindes med samfundsetikken. Boesak nævner ikke, at Gandhi udviklede sin ikke volds-tænkning netop i årene 1893-1914, ${ }^{16}$ hvor han opholdt sig i Sydafrika med hen-

16. Gandhi (1869-1948) var leder af Indiens uafhængighedsbevægelse. Han blev myrdet af en fanatisk hindu, fordi han arbejdede for forsoning mellem hinduer og muslimer. 
blik på at forbedre indernes vilkår. ${ }^{17}$ Boesak har kunnet se linjer fra dette til sin samtids Sydafrika, hvor der var 4 befolkningsgrupper; hvide, sorte, farvede og indere, og hvor der var adskillelse mellem det hvide mindretal og de tre andre grupper.

King indså, at sandheden, kærligheden og retfærdigheden har et ontologisk fortrin. Derfor skal man ikke acceptere det onde i passivitet. Man skal modigt konfrontere det onde på en ikke-voldelig måde, for vold skaber blot mere bitterhed og vold. Tillige lærte King af Paul Tillich, at kærlighed er en enhedsskabende magt i livet, der kan overvinde den adskillelse, som skyldes synden (Boesak 1976,8).

King kunne ved overtagelse af sine inspirationskilder ende i en position som til forveksling lignede mange hvide filosofisk prægede liberalteologer. Men Boesak finder en dybere kilde, som beskytter King mod at blive liberalteolog. Det er en forpligtelse til befrielse, til kraftfuld sort kristendom. Boesaks tolkning indebærer, at denne kreative spiritualitet er en væsentlig faktor for afroamerikanernes modstand mod den åndelige og politiske undertrykkelse fra de hvides side. Det sorte er en afgørende faktor.

I centrum for Kings kristne tro står Gud, og Gud er virksom i historiens forløb på en måde, som udtrykker, at Gud vil overvinde det onde. Derfor må enhver kristen kæmpe for retfærdigheden. Mennesket er sat ind som deltager i Guds universelle kamp mod det onde. Kærligheden skal derfor være basis for en revolutionær kristen praksis. King pegede på Jesu befrielsesmanifest i Luk 4,18-21, sådan som mange befrielsesteologer, deriblandt Boesak, senere har gjort det (Boesak 1976,10-11).

King var enig i Marx' syn på forholdet mellem rig og fattig, altså i opfattelsen af klassekampen. For King er evangeliet pr. definition et socialt evangelium. Da dette indebærer, at Gud fører en universel kamp mod det onde, betyder det, at man ikke kan retfærdiggøre den racebetingede undertrykkelse. King mener, at der er et universelt behov for etik. Men i praksis bliver etikken hos King kontekstuel, for det er de sorte, der skal kæmpe for befrielse. Centralt i tanken om Guds kongedømme står kærligheden, og den forener det individuelle og det sociale i etikken. Kings etik er ikke eksklusiv. King mener, at evangeliet hverken er individuelt eller kollektivt, men en syntese af begge dele.

Boesak finder det afgørende for Kings opfattelse, at kristen etik er indeholdt $\mathrm{i}$ ordet befrielse. Dette er det afgørende for sorte kristne. Det er tydeligt, at Boesak finder det relevant, fordi King er sort og kæmper for de sorte. Det tager Boesak med sig fra studiet af Kings

17. Willa Boesak, God's Wrathfull Children - Political Oppression and Christian Ethics (Grand Rapids: William B. Eerdmans Publishing Company 1995), 35-68. 
etik. Det sker, selvom Boesak ikke tænker ontologisk i klassisk forstand, hvor ontologi er en totalforklaring, der har en universel gyldighedsprætention. Boesak holder sig til det konkrete problem i den konkrete kontekst.

\section{Malcolm X' muslimske ontologi}

Boesaks forhold til Malcolm X er mere kompliceret. Malcolm X var søn af en sort baptistpræst. Malcolm X' far var medlem af Marcus Garveys "Back to Africa-movement". En aften, da Malcolm X' mor var gravid og ventede Malcolm X, og hvor hun var alene hjemme, kom en gruppe fra Ku Klux Klan og smadrede alle ruder i huset. Som dreng oplevede han sit hjem brænde ned til grunden. Hans far blev myrdet af Den hvide Legion. Bitterheden over mordet på faderen prægede Malcolm X, og han kom ud i kriminalitet. Under en fængsling mødte han Elijah Muhammad, hvorefter han konverterede til islam og blev medlem af både Nation of Islam og Black Muslims. En hovedtanke hos Black Muslims er, at den hvide mand fra naturen er ond. Han er en slange, som ikke kan gøre det rette, og en djævel, som snart vil blive tilintetgjort (Boesak 1976,14).

Malcolm X engagerede sig i kampen mod den hvide mand. Han reagerede imod den hvide mands magt, som kom til udtryk i slaveriet. Kristendommen var en slavereligion. Befrielseskampen var meningsfuld, fordi Harmagedon snart vil indtræde. Når det sker, vil Allah gøre den sorte mand lige med eller overordnet den hvide. For Malcolm X udgjorde Koranen og Elijah Muhammad inspirationskilderne. Hans etik kom til at handle om befrielse på en stærkere måde end hos King. Hvor King regner med en personlig Gud, der i historiens forløb kalder mennesker ind som sine medarbejdere, regner Malcolm X med en sort Gud ved navn Allah, som arbejder direkte gennem sorte mennesker. De sorte mennesker er guddommelige. Tænkningen hos Black Muslims indebærer, at "The Original man, Elijah Muhammad teaches, is none other than the black man. He is Allah." (Boesak 1976,19). Det er en opsigtsvækkende forskel i forhold til klassisk islam. Men budskabet for de sorte muslimer indebærer gode nyheder for fårene (de sorte) og dårlige nyheder for ulvene (de hvide). I videre forstand rummer dette ingen mulighed for opblødning, for der er ingen mulighed for omvendelse eller konversion for den hvide mand. Han er pr. definition ond, fordi han er hvid.

Når sådanne tanker kunne slå rod og blive udbredt blandt afroamerikanerne, bekræfter det Boesak i hans tese, at King og Malcolm $\mathrm{X}$ skal forstås ud fra hinanden. De stod begge for en afgørende ven- 
ding blandt afroamerikanerne, et opbrud imod fornedrelsen. King var ansvarlig for radikaliseringen af den sorte kristenhed, mens Malcolm X var ansvarlig for dekristianiseringen af den sorte radikalisme (Boesak 1976,13). Begge dele skyldtes radikaliseringen af forholdet mellem sorte og hvide.

Overvejelser om muslimernes befrielse er også relevant for Boesak, fordi der i Sydafrika er en del muslimer. Muslimerne var kommet til Sydafrika fra Indonesien, Kina og Malaysia som slaver. Indledningen af den sunnimuslimske umma i Sydafrika henføres til Shaykh Yusuf, der kom til Cape Town i 1694. De fleste muslimer i Sydafrika lever i Cape Town, hvor der ved 300 års jubilæet for det muslimske samfund var over 100 moskeer og mellem en halv og en hel million muslimer. Muslimernes vilkår under apartheid var ikke gunstige. De måtte ikke praktisere deres religion offentligt. Muslimske børn var illegitime, for kun kristne var fuldværdige. Der var rivalisering mellem farvede kristne og farvede muslimer. Det vanskeliggjorde en fælles kamp for befrielse. ${ }^{18}$

\section{Separation eller integration}

King mener, at hvide og sorte behøver hinanden i kampen for et bedre samfund. Dette bliver også Boesaks vision i den sorte etik. I Sydafrika var der i 1970-erne fællesskabsfascisme. Det var ikke kun hvide, som isolerede sig i grupper, men også sorte. Blandt de første sorte teologer var der bevidsthed om dette, og nogle f.eks. Mpunzi understregede skabelsesdimensionen mere end Boesak. Mpunzi mente, at den sorte befrielsesteologis opgave er at tage udgangspunkt $i$, at Gud har skabt mennesker med lige værd. Derfor må de sorte modarbejde den nedvurdering, som de hvide har udsat dem for. De sorte må elske deres sorthed, fordi Gud har skabt dem sådan. Det skal føre til, at alle elsker og accepterer hinanden som Guds skabninger. ${ }^{19}$

Boesak er drevet af en indignation over de hvides undertrykkelse af de sorte. Boesak henter inspiration specielt fra King. Når Malcolm X også er relevant for Boesak trods hans separationstanke, skyldes det den størrelse, som den sorte søgen efter befrielse repræsenterer. Den-

18. Ove Nyman, "Intermarriage - or just living together? The Relations between Christian and Muslims in Cape Town", Towards a New South Africa - A Field Study Report on Church and Social Change, ed. Ove Nyman (Uppsala: Uppsala Universitet Teologiska institutionen 1994), 3-41.

19. Ananias Mpunzi, "Black Theology as Liberation Theology", Black Theology The South African Voice, ed. Basil Moore (London: C. Hurst \& Company 1973), 130-140. 
ne størrelse er betydningsfuld for de sorte, og den rummer et element af solidaritet. De sorte har sans for de tilgrænsende kontekster, hvor andre sorte er undertrykte. King engagerede sig i kampen for sort befrielse, fra hvid undertrykkelse til fornyet fællesskab mellem sorte og hvide. Malcolm X kæmpede for sort befrielse til et samfund, hvor sorte og hvide skal leve adskilt. De principper, der ligger til grund for en aktiv befrielseskamp, er forskellige. King går ind for en ikke-voldelig kamp, mens Malcolm X går ind for gengældelsens vold begrundet i Moselovens lex talionis, dvs. øje for øje, tand for tand osv. Men begge har frihed fra undertrykkelse, retfærdighed, lighed og fred for de sorte, som mål for deres bestræbelser.

Det er ikke ofte, at Boesak giver sin egen mening til kende. Et sted skriver han, at Malcolm X klarere end King ser de hvide amerikaneres hykleri, når de bifalder ikke-volds-princippet i forsøget på at få et bedre samfund. Malcolm X ser hykleriet $i$, at unge sorte amerikanere blev sendt til Korea og Vietnam for at kæmpe for det demokrati, som de sorte ikke selv har del i hjemme i USA, når de ikke har samme rettigheder som hvide. Malcolm X har et skarpere blik for de hvides økonomisk-politiske undertrykkelse, den såkaldte dollarisme, som har vist sig i kolonisering og slaveri (Boesak 1976,29,44). Malcolm $\mathrm{X}$ går dog betydeligt længere, end Boesak vil acceptere. Malcolm X ønsker at etablere en stat i USA, som er forbeholdt sorte, og hvor hvide er udelukket. Her tager Boesak selv stilling og siger, at det er uacceptabelt, fordi det ligner de hvides apartheid-ideologi i Sydafrika (Boesak 1976,30). King, Malcolm X og Boesak vil alle have befrielse for de undertrykte sorte, men endemålet er forskelligt.

\section{Sammenfatning på Boesaks forstudier}

Boesaks studier i King og Malcolm X viser et af de elementer, som Boesak i særlig grad anser for vigtige i opbygningen af sin befrielsesetik. Den sorte bevidsthed er åbenbart en transkonteksuel størrelse, som findes i både kristen og muslimsk kontekst. Det sorte giver de sorte sans for andre sorte i tilgrænsende kontekster. Men de sorte udgør også en kontekst, hvor de sorte er samlet som gruppe, uanset om det er i Nordamerika eller i Sydafrika.

Det var Kings og Malcolm X' fælles kritik af skavankerne i det imperialistiske kapitalistiske system, der gjorde dem til farlige personer for det amerikanske samfund. Deres etik var afledt af forskellige kilder. Det afgørende var for Boesak, at både King og Malcolm X reflekterede over deres egne bidrag til de sortes kamp, og at deres bidrag var anvendelige. Boesak værdsatte Kings ikke-voldsholdning, 
fordi den var årsag til, at en egentlig borgerkrig blev undgået i USA. Volden havde i givet fald været udsigtsløs og umoralsk.

Boesak konkluderer, at Kings teologi var en befrielsesteologi, og det frugtbare var en kritik af, at kirken generelt har bekymret sig mere om livet hinsides, end om livet her på jorden. King sagde, at det var blasfemi, når den hvide mand gjorde Gud til sin partner i udnyttelsen af sorte, og King mente ikke, at der i religionens verden har været et større kætteri (Boesak 1976,46-47). Kings teologi udvikledes med årene til en sort teologi. Boesak mener, at King er den betydeligste, fordi han er den første sorte teolog, der har etableret en socialetik, der er gået til hjertet af sagen.

Studiet af en kristen og en muslimsk afroamerikansk befrielsestænker har relevans for etableringen af Boesaks sorte etik. Boesak tænker ikke i lukkede kontekster. Inddragelsen af en muslimsk tænker er relevant, fordi der også er undertrykte muslimer i Sydafrika. Der var muligheder for, at kristne og muslimer kunne kæmpe sammen for befrielse og retfærdighed i Sydafrika. Det var ikke selvfølgeligt, at muslimer ville være med i denne kamp, fordi de var en diskrimineret og magtesløs marginalgruppe. ${ }^{20}$

\section{Situationel kontekstuel etik}

Boesak har sans for de tilgrænsende kontekster. Han har sans for, hvad der gør kontekster forskellige og for, hvad der binder sammen. Han er målrettet for at løse problemet i sin egen oprindelige kontekst.

Boesaks liv begyndte ikke på solsiden af livet. Faderen døde, da Boesak var dreng. Moderen var stærkt troende og arbejdede hårdt for børnene. Boesak forstod, hvad det vil sige at tro på en Gud, der tager sig af enker, faderløse, svage og nødlidende. Som voksen blev han bevidst om arbejdsløshed, bolignød, underernæring, sygdom og manglende uddannelsesmuligheder. De psykosociale følger af dette var omstrejfende drengebander, blodig vold, kriminalitet, udbredelse af narkotika, alkoholisme og prostitution i de sortes ghettoer. Det var tillige en tilspidsning af samfundets hovedproblemer, etnofobi, genofobi, slaveri, racistisk diskrimination og økonomisk udbytning. Da Boesak studerede ved kirkens seminar for farvede i Bellville, oplevede han ikke lærerne som kompetente. Deres teologi var pietistisk og spiritualiserende. Han oplevede ikke deres undervisning relevant i forhold til de problemer, han kendte. Han søgte derfor noget relevant, og den sorte teologi, som han vil bygge op, er løsningen på dette

20. Gerrie Lubbe, "Christians, Muslims and Liberation in South Africa", Journal of Theology for Southern Africa issue 56 (1986), 24-33. 
etiske problem. Befrielse bliver for Boesak en hermeneutisk nøgle, hvormed han forstår indholdet af bibelteksterne på sin måde. Befrielse bliver for Boesak karakteriseret af forandring af de begrænsende livsvilkår, ophævelse af alle diskriminerende love, gennemførelse af menneskerettighederne, så alle mennesker kan tage del i det økonomiske, sociale, politiske og kulturelle liv på lige vilkår. ${ }^{21}$ Boesak betegner sin etik som en transformationsetik (Boesak 1977,145).

Boesak udtrykker, at hans teologi er situationel (Boesak 1977,13,144) og kontekstuel (Boesak 1977,143). Nogle af Boesaks formuleringer lægger op til, at det situationelle og det kontekstuelle er synonyme størrelser. ${ }^{22}$ Det betyder, at han betragter sin befrielsesteologiske etik som gyldig i den situation, hvor den sorte gruppe mennesker er undertrykt i den sydafrikanske kontekst. Men gyldigheden udstrækkes til de mennesker og de situationer og de tider og de steder, hvor de sorte er undertrykt. Det er her, at transkontekstualiteten spiller en rolle. Evangeliet skal fortolkes således, at de sorte kan forstå det. De sorte vil kunne forstå en bibelsk holistisk teologi, men de forstår ikke vestlige abstraktioner. En bibelsk holistisk teologi vil efter Boesaks opfattelse kæmpe for befrielse fra religiøs, økonomisk, psykologisk og kulturel afhængighed.

Når Boesak udtrykker, at den sorte teologi er kontekstuel, distancerer han sig fra Cones teologi som en regionalteologi (Boesak 1977,143) ${ }^{23}$ Boesaks teologi er situationel i den forstand, at hvis de hvides undertrykkelse af sorte elimineres, så er der ikke længere behov for hans udgave af den sorte etik. Boesaks etik er imidlertid ikke en situationsetik, hvor intet er givet på forhånd. Tværtimod afgrænser Boesak sig fra en sådan etik. Han forudsætter Guds Ord ud fra hvilket, der skal være en kritisk refleksion over den konkrete situation (Boesak 1977,143). Det er en transkontekstuel størrelse, Guds Ord, Jesu Kristi befrielse, som skal kontekstualiseres. Dermed er hans kontekstuelle etik mere end en situationsetik. Det skyldes forudsætningerne Jesu befrielse og det sorte. Det er forskellen på Boesaks og

21. Erhard Kamphausen, "Schwarze Theologie: Allan Aubrey Boesak, Südafrika", Theologen der Dritten Welt, ed. Hans Waldenfels (München: Verlag C.H.Beck 1982), 98-105.

22. Det er oplagt i Boesak 1977,143 og Allan Boesak, "Liberation Theology in South Africa", African Theology en Route, ed. Kofi Appiah-Kubi and Sergio Torres (Maryknoll: Orbis Books 1979), 171. Et sted bruges begrebet kontekstuel i parentes som forklaring til det situationelle (Allan Boesak, "Coming in out of the Wilderness", The Emergent Gospel - Theology from The Developing World, ed. Sergio Torres and Virginia Fabella (Maryknoll: Orbis Books 1978), 87.

23. Allan Boesak, "Auszug aus Der Wüste. Auf Dem Wege in eine Welt der Menschen", Theologie im Konfliktfeld Südafrika - Dialog mit Manas Buthelezi, ed. Ilse Tödt (München: Kösel-Verlag 1976), 152-155. 
Cones etik. Cones teologiske udgangspunkt kan ikke kontekstualiseres andre steder end hos de undertrykte sorte. Det er her, at Boesaks første transkontekstuelle forudsætning, befrielsesevangeliet, kan anvendes i andre kontekster, hvor der er undertrykkelse pga. fattigdom, religion mv.

\section{Diskussion med Cone}

Den sorte teologi i Sydafrika reflekterede ikke over begrebet sort magt, før Boesak satte det på dagsordenen. James Cones Black Theology and Black Power fra 1970 var ikke slået igennem. ${ }^{24}$ Men fra 1977 kom refleksionen over sort magt med Boesaks afhandling, hvor der også diskuteres med Cone.

Boesak mener, at Gud åbenbarer sig i situationen. Gud virker ved, at Guds ord og de sortes erfaring får mennesker til at søge befrielse. Boesak kritiserer imidlertid Cone for at give de sortes situation åbenbaringsstatus. Boesak skriver, at de sortes erfaring er rammen for, hvordan de sorte forstår Guds åbenbaring i Jesus Kristus. Per Frostin gør opmærksom på en lille tilføjelse i Boesaks tekst: "No more, no less" (Boesak 1977,12). Deri ligger to afgrænsninger. På den ene side ligger der en afgrænsning imod en forestilling om en universel åbenbaring hævet over tid og sted. På den anden side er det en afvisning af forsøg på at gøre de sortes situation absolut. ${ }^{25}$ Det første er tilfældet i meget vestlig teologi, og det sidste er tilfældet hos Cone.

Boesaks befrielsesteologi bygger ikke på en historisk kløft eller en epistemologisk kløft. Den bygger på en sociologisk kløft mellem undertrykkere og undertrykte, mellem hvid og sort, mellem mand og kvinde. Boesak definerer befrielsen, så den ikke blot er en del af evangeliet eller i overensstemmelse med evangeliet, men snarere indhold og ramme for Jesu Kristi evangelium. Men sort teologi "believes that in Jesus Christ the total liberation of all people has to come" (Boesak 1977,109). Det er mere åbent, end når Cone skriver: "liberation is not only consistent with the gospel but is the gospel of Jesus Christ". ${ }^{26}$

Boesaks kontekstuelle etik falder ikke i samme grøft som Cones regionale etik. Thor Halvor Hovland mener alligevel ikke, at Boesaks

24. Theo Sundermeier, "Schwarzes Bewusstsein - Schwarze Theologie", Christus, der schwarze Befreier, ed. Theo Sundermeier (Erlangen: Verlag der Ev.-Luth. Mission 1973), 28.

25. Per Frostin, Liberation Theology in Tanzania and South Africa - A First World Interpretation (Lund: Lund University Press 1988), 160.

26. James H. Cone, Liberation - A Black Theology of Liberation (Philadelphia: J.B.Lippincott Company 1970), 17. 
etik er klar. De sortes erfaring og situation må ikke i sig selv få åbenbaringskarakter. ${ }^{27}$ Men situationsanalysen kommer let til at blive bestemmende for læsningen og erkendelsen af indholdet i bibelteksterne. For at undgå Cones regionalteologi må følgende tre betingelser opfyldes: 1) Sort teologi skal være kontinuerlig selvkritisk i lys af Guds ord. 2) Sort teologi skal virke frigørende for alle mennesker. 3) Sort teologi skal være eskatologisk. ${ }^{28}$ Cones teologi sigter på befrielse for de sorte. Boesak sigter på, at sort teologi skal være frigørende for alle mennesker (Boesak 1977,10,152). Både de hvide undertrykkere skal sættes fri af deres trang til at undertrykke og de sorte skal sættes fri fra den konkrete undertrykkelse. Det er den afgørende forskel.

Cone tager udgangspunkt i den eksistentielle situation hos det undertrykte samfund. Befrielsen er Jesus Kristi evangelium. Cone siger, at Gud er alle undertryktes Gud. Deri ligger det universelle mærke, skriver Cone. Det er dog ikke en velvalgt brug af begrebet universalitet, for Cone sætter en radikal skelnen mellem mennesker. Befrielsen af sorte er Guds befrielse. Amerikansk hvid teologi har intet at sige til folkedrabet på indianerne, og at de sorte blev gjort til slaver. Cone slår fast, at kristen teologi har sit centrum i Jesus Kristus. Denne absolutte åbenbaring af Gud i Jesus Kristus viser sig i, at Gud arbejder i det sorte samfund gennem sort teologi. Sort teologi er den eneste mulige teologi i samtiden. Sort teologi giver sorte mod til en revolte imod de hvides sociale og politiske strukturer (Cone 1970,4445). Sort teologi er ifølge Cone Guds åbenbaring til sorte og hvide i Amerika. Cone mener, at hvid teologi er Antikrists teologi. Denne teologi var passiv i forhold til udryddelsen af indianerne, forfølgelsen af jøderne og undertrykkelsen af mexicanere. Dette blev gjort i Guds navn og til fordel for det hvide samfunds patriotisme. Cone mener, at $i$ hvidheden ligger den sataniske natur, så at "whiteness is the symbol for the Antichrist" (Cone 1970,29). Ifølge Cone hjælper det ikke, at liberale hvide siger, at 2/3 af Amerikas fattige er hvide. Det løser ikke den hvide racismes problem. Gud er ikke farveblind i kampen mellem hvide og sorte. Ifølge Cone foretager Gud en kvalificeret identifikation med de sorte. Sorthed er et ontologisk symbol og en synlig virkelighed på undertrykkelsen i Amerika. Derfor må teologien blive anti-hvid, for at støtte sortheden. Teologien må befries fra hvidheden, og hvis den hvide teologi vil blive sand teologi, må den ophøre med at være hvid og i stedet blive sort teologi (Cone 1970,17-34).

27. Thor Halvor Hovland, "Luthersk kontekstuel teologi", Norsk Tidsskrift for Misjon vol. 50/1 (1996), 5.

28. Thor Halvor Hovland, "Svart teologi som frigjøringshermeneutikk", Tidsskrift for Teologi og Kirke 64/4 (1993), 245-248. 


\section{Transkontekstuel åbenhed}

Boesak reagerer på denne eksklusivitet. Boesak brænder for de sortes befrielse, men han ønsker samtidig befrielse for alle, både for undertrykkere og for undertrykte. Cones kontekstuelle etik er begrænset til en oprindelseskontekst, og dér bliver den. Boesaks etik er mere fleksibel. Den har sans for tilgrænsende kontekster og vil kunne anvendes af undertrykte sorte, uanset hvor de befinder sig. Boesaks sorte etik vil med sin fastholden af Jesu befrielse kunne anvendes i alle kontekster, hvor der er undertrykkelse pga. race og hudfarve. Ved en dekonteksualisering og en rekontekstualisering vil den kunne finde nye anvendelseskontekster for andre grupper af mennesker, som er undertrykt pga. race og hudfarve, og som sådan er den transkontekstuel. 